\title{
SISTEM INFORMASI PEMERINTAHAN DESA MENGGUNAKAN FRAMEWORK ZACHMAN STUDI KASUS DESA TRIWIDADI, PAJANGAN, BANTUL
}

\author{
Aulia Pasca Sahida, Heru Cahya Rustamaji, Hafsah \\ Jurusan Teknik Informatika Fakultas Teknik Industri UPN "Veteran" Yogyakarta \\ Jl. Babarsari 2 Tambakbayan Yogyakarta \\ e-mail : pascasahida95@gmail.com, herucr@gmail.com, hafsahotha@gmail.com
}

\begin{abstract}
Understanding the magnitude of the usefulness provided by E-Government, the Indonesian government in 2003 issued a policy for the implementation of E-Government namely Presidential Instruction no 3 of 2003 (Hartono \& Mulyanto, 2010). The Presidential Instruction is a directive and guidance in implementing E-Government, one of the purposes is to erode the cynicism and increase the effectiveness within government agencies. To build a systematic and appropriate E-Government in the analysis of planning and design can be Is done by utilizing Zachman framework. Analysis and design of this research will use Zachman Framework. Zachman Framework is used because when compared with other enterprise architecture, Zachman Framework is the most complete to do documentation (Christianti \& Try, 2009). The excess will be able to solve the problem if in the future there is a change in one or several parts of E-Government that has been built, no need to change from the beginning, just see the documentation, on which part will do the change.
\end{abstract}

\section{Keywords : E-Government, Zachmaan Framework, Village Information System}

Memahami besarnya kegunaan yang diberikan oleh E-Government, pemerintah Indonesia pada tahun 2003 mengeluarkan kebijakan untuk implementasi E-Government yaitu Instruksi Presiden no 3 tahun 2003 (Hartono \& Mulyanto, 2010). Instruksi Presiden tersebut adalah sebagai arahan dan pedoman dalam menerapkan E-Government, yang salah satu tujuanya adalah untuk mengikis kebirokrasian dan meningkatkan efektifitas di dalam instansi pemerintahan.. Untuk membangun E-Government yang sistematis dan sesuai dengan kebutuhan, dalam melakukan analisis perencanaan dan perancangan dapat dilakukan dengan memanfaatkan framework Zachman.. Analisis dan perancangan penelitian ini akan menggunakan Zachman Framework. Zachman Framework digunakan karena jika dibandingkan dengan enterprise architecture lainya, Zachman Framework adalah yang paling lengkap untuk melakukan pendokumentasian (Christianti \& Try, 2009). Kelebihan tersebut akan dapat mengatasi masalah jika dikemudian hari ada perubahan pada salah satu atau beberapa bagian EGovernment yang telah dibangun, tidak perlu merubah dari awal, cukup melihat pendokumentasianya, pada bagian mana yang akan dilakukan perubahan.

Kata Kunci : E-Government, Framework Zachmaan, Sistem Informasi Pemerintahan Desa

\section{PENDAHULUAN}

Tugas utama instansi pemerintahan adalah melayani masyarakat, sehingga setiap kali masyarakat memerlukan pelayan akan berhadapan dengan instansi pemerintahan setempat.. Salah satu instansi pemerintahan yang paling sering berhadapan langsung dengan kepentingan masyarakat adalah Instansi pemerintahan desa (Kelurahan). Seperti yang di sebutkan di dalam Undang-Undang nomor 6 tahun 2014, pemerintahan desa adalah sebagai penyelenggara urusan pemerintahan dan kepentingan masyarakat setempat (Yustisia, 2015). Dapat dipahami dalam Undang-Undang tersebut bahwa Pemerintahan Desa diberikan tugas dan tanggung jawab atas terselenggaranya roda Pemerintahan dan memberikan pelayanan kepada masyarakat daerah setempat.

Berkembangnya teknologi informasi dalam masa melenial ini bergitu cepat, sehingga tidak terelakan akan membawa dampak perubahan. Tidak terkecuali sektor pemerintahan yang akan terkena dampaknya dalam menjalankan roda pemerintahan dan kepentingan masyarakat dengan menerapkan teknologi informasi. Penerapan teknologi informasi dalam sektor 
pemerintahan disebut dengan E-Government. Memahami besarnya kegunaan yang diberikan oleh E-Government, pemerintah Indonesia pada tahun 2003 mengeluarkan kebijakan untuk implementasi E-Government yaitu Instruksi Presiden no 3 tahun 2003 (Hartono \& Mulyanto, 2010). Instruksi Presiden tersebut adalah sebagai arahan dan pedoman dalam menerapkan EGovernment, yang salah satu tujuanya adalah untuk mengikis kebirokrasian dan meningkatkan efektifitas di dalam instansi pemerintahan.

Untuk membangun E-Government yang sistematis dan sesuai dengan kebutuhan, dalam melakukan analisis perencanaan dan perancangan dapat dilakukan dengan memanfaatkan Enterprise Architecture. Digunakanya Enterprise Architecture untuk memperoleh efektifitas desain dan pengembangan arsitektur dalam memenuhi kebutuhan tujuan (Setiawan, 2009). Berdasarkan survey yang telah dilakukan oleh Institute for Enterprise Architecture Development (IFEAD) pada tahun 2003, enterprise architecture yang paling banyak digunakan saat ini adalah Zachman, TOGAF, IAF, dan FEAF (IFEAD, 2003). Pemilihan penggunaan enterprise architecture tentu harus menyeseuaikan antara karakteristik enterprise arsitektur dengan kebutuhan dan tujuan yang ingin dicapai organisasi.

Dalam lingkungan Pemerintahan desa Triwidadi, penerapan E-Government pada tingkat internal organisasi pemerintahan belum diimplementasikan. Sistem penyelenggaraan pemerintahan dan kepentingan masyarakat masih bersifat konvensional. Berdasarkan hasil wawancara, diskusi, dan pengamatan secara langsung yang dilakukan pada perangkat desa Pemerintahan desa Triwidadi, selama menjalankan penyelenggaraan pemerintahan terdapat beberapa keluhan dari masyarakat, hambatan, dan beberapa masalah yang bersifat mendasar. Seperti keluhan masyarakat dalam pelayanan penerbitan surat keterangan yang tertunda. Dalam beberapa kasus, tertundanya penerbitan surat keterangan yang diminta masyarakat karena harus dilakukan validasi data tertentu. Selanjutnya hambatan surat masuk dari instansi lain yang tidak segera ditindak lanjuti, yang dikarenakan urutan birokrasi mengharuskan beberapa pihak bertemu secara langsung terlebih dahulu untuk menindak lanjuti surat yang masuk. Kemudian permasalahan master data kartu keluarga yang rawan hilang dan kadang tidak diperbarui. Permasalahan ini disebabkan karena master data kartu keluarga yang dimiliki pihak pemerintahan Triwidadi berupa hard copy dari kartu keluarga, sehingga ketika salah satu kartu keluarga diambil untuk kepentingan tertentu dan lupa tidak dikembalikan akan menyebabkan hilangnya data dari kartu keluarga tersebut. Dan juga ketika masyarakat melakukan pelaporan perubahan data kartu keluarga dengan menyerahkan salinan hard copy kartu keluarga dan petugas tidak mengganti kartu keluarga yang lama dengan yang baru, maka master data yang dimiliki pihak pemerintahan Triwidadi bukan yang terbaru.

\section{METODE PENELITIAN}

Metodologi penelitian adalah urutan langkah-langkah sistematis dalam membangun implementasi sistem E-Government di lingkungan pemerintahan desa Triwidadi. Langkahlangkah tersebut adalah sebagai berikut:

\section{Observasi}

Observasi merupakan langkah awal yang dilakukan dalam penelitian ini. Dalam melakukan observasi dilakukan dengan cara melakukan pengamatan secara langsung di lingkungan pemerintahan desa Triwidadi untuk memperoleh gambaran secara jelas mengenai kondisi nyata di lapangan.

2. Studi Pustaka

Setelah mendapatkan gambaran secara real kondisi di lapangan melalui observasi awal yang dilakukan, maka untuk mendukung penelitian yang sesuai dengan kondisi di lapangan, dilakukan penggalian ilmu yang mendukung melalui studi pustaka. Studi pustaka dilakukan dengan mencari dan memahami buku-buku, artikel, jurnal, dan karya ilmiah lainya yang berkaitan dengan hasil gambaran observasi awal.

3. Wawancara dan Diskusi

Wawancara dan diskusi dilakukan dengan bertemu secara langsung pada perangkat pemerintahan desa Triwidadi. Wawancara dan diskusi bertujuan untuk memperoleh gambaran pemahaman dan data yang lebih mendalam dari observasi awal yang telah dilakukan. Terutama pemahaman permasalahan yang terjadi di lingkungan pemerintahan desa Triwidadi. Wawancara dan diskusi dimungkinkan dilakukan berulang ulang agar mendapatkan pemahaman yang valid untuk selanjutnya dilakukan analisis. 


\section{Analisis}

Analisis dilakukan bersamaan dengan diperolehnya pemahanan valid dari hasil wawancara dan diskusi. Analisis dimaksudkan untuk menentukan arah penelitian yang akan dilakukan, agar sesuai dengan gambaran pemahaman permasalahan dan data yang ada di lapangan. Dalam tahap ini digunakan beberapa scope bagian dari Zachman Framework yang memiliki karakteristik sebagai langkah analisis.

\section{5. $\quad$ Perancangan dan Implementasi}

Setelah didapatkan arah penelitian yang sesuai selanjutnya dilakukan perancangan terhadap sistem E-Government, dan dilanjutkan dengan implementasi pembangunan sistem EGovernment. Untuk tahap perancangan dan implementasi juga akan menerapkan beberapa scope Zachman Framework yang memiliki karakteristik yang mendukung untuk melakukan perancangan dan implementasi.

Zachman framework digambarkan dengan ilustrasi berupa matriks yang memiliki enam baris dan enam kolom. Baris yang ada dalam Zachman framework mewakili enam sudut pandang perspektif. Kolom menunjukun pendefinisian enam aspek sebagai fokus atau abstraksi (Yunis \& Theodora, 2012). Awal kemunculan Zachman framework dipublikasikan oleh John Zachman dalam sebuah publikasi IBM System Journal tahun 1987. Zachman framework yang dipublikasikan pertama kali tidaklah seperti kebanyakan Zachman framework yang digunakan saat ini. Publikasi pertama kali Zachman framework berupa matriks yang terdiri dari enam baris dan tiga kolom. Selanjutnya Zachman framework mengalami perkembangan berupa penambahan tiga kolom, setelah dilakukan perluasan dan formulasi oleh Sowa dan Zachman pada tahun 1992, sehingga strukturnya menjadi matriks dengan enam baris dan enam kolom seperti yang banyak digunakan saat ini (Surendro, 2009). Sebagai penjelasan lebih lanjut bentuk Zachman framework yang berupa matriks 6 baris dan enam kolom dapat dilihat pada gambar 2.4 berikut.

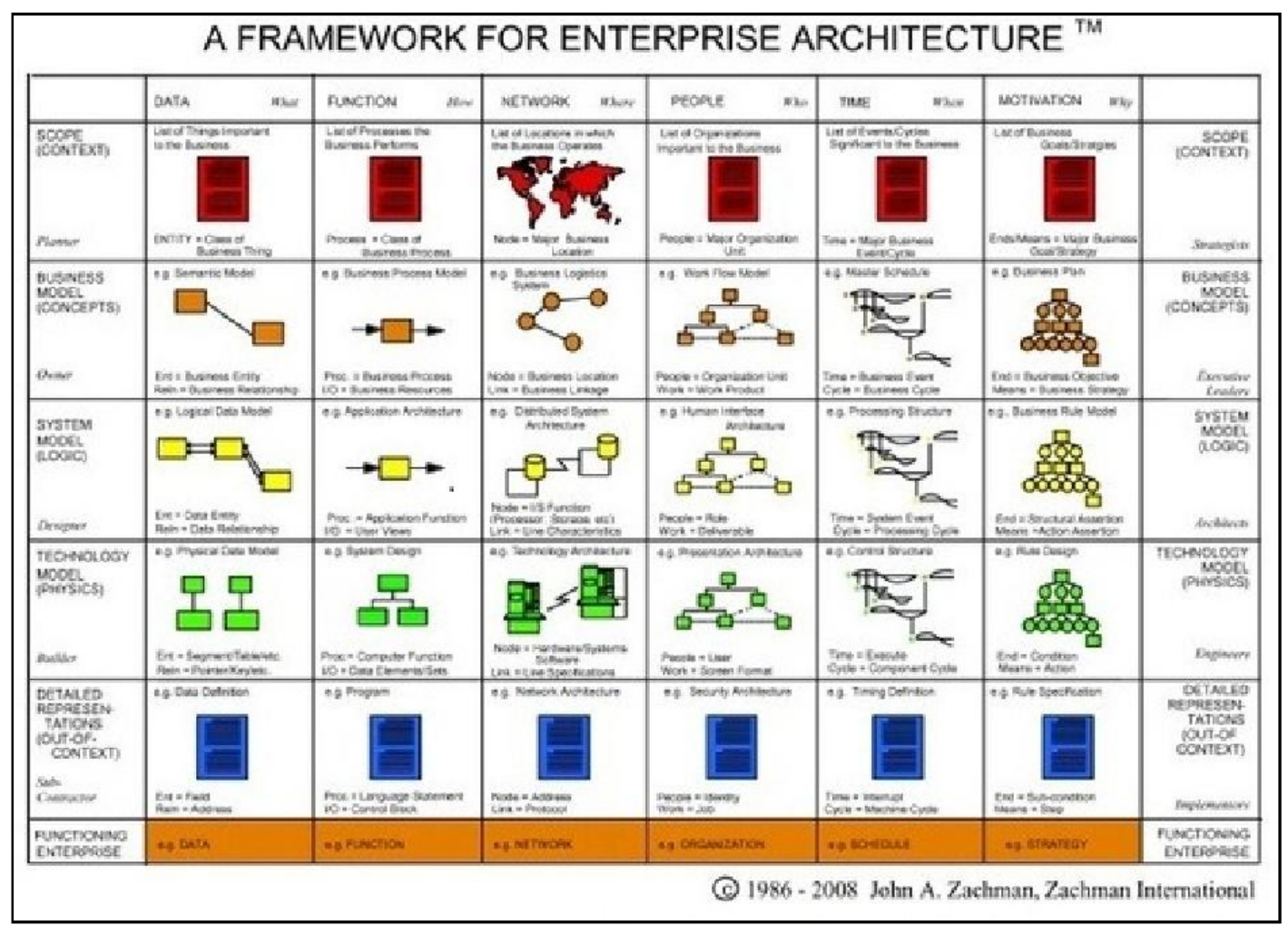

Gambar 2.4 Struktur Zachman Framework

Seperti yang sudah dijelaskan pada bagian sebelumnya, bahwa Zachman framework memiliki struktur berupa enam baris sudut pandang perspektif dan enam kolom aspek sebagai fokus. 
Perincian klasifikasi dari enam sudut pandang perspektif yang ada di dalam matriks Zachman framework dapat dijelaskan melalui tabel 2.1 berikut ini (Yunis \& Theodora, 2012).

\begin{tabular}{|l|l|l|l|}
\hline \multicolumn{1}{|c|}{ Perspektif } & \multicolumn{1}{c|}{ Tujuan } & \multicolumn{1}{c|}{ Hasil } & \multicolumn{1}{c|}{ Batasan } \\
\hline Planner & $\begin{array}{l}\text { Mendefinisikan } \\
\text { lingkup (scope) }\end{array}$ & Definisi lingkup & $\begin{array}{l}\text { Keuangan dan } \\
\text { peraturanya }\end{array}$ \\
\hline Owner & $\begin{array}{l}\text { Mendfinisikan bentuk } \\
\text { dari produk }\end{array}$ & Model bisnis & $\begin{array}{l}\text { Kebijakan dan } \\
\text { penggunaanya }\end{array}$ \\
\hline Designer & $\begin{array}{l}\text { Mendefinisikan } \\
\text { bentuk logika/asbtrak } \\
\text { dari produk }\end{array}$ & Model sistem & $\begin{array}{l}\text { Lingkungan dan } \\
\text { teknologi yang akan } \\
\text { digunakan }\end{array}$ \\
\hline Builder & $\begin{array}{l}\text { Mendeskripsikan } \\
\text { pengembangan } \\
\text { produk } \\
\text { penerapanya }\end{array}$ & Model teknologi & $\begin{array}{l}\text { Mengembangkan dan } \\
\text { menyiapkan } \\
\text { kebutuhan teknologi }\end{array}$ \\
\hline Sub Contractor & $\begin{array}{l}\text { Mendeskripsikan } \\
\text { komponen }\end{array}$ & $\begin{array}{l}\text { Out-of-context } \\
\text { models }\end{array}$ & $\begin{array}{l}\text { Penerapan dan } \\
\text { integrasi }\end{array}$ \\
\hline
\end{tabular}

Dari sudut pandang (Perspektif) yang telah diklasifikasikan diatas, memiliki keterkaitan dengan aspek pada kolom Zachman sebagai fokus pendefinisian masing-masing sudut pandang. Penguraian aspek-aspek tersebut adalah sebagai berikut (Surendro, 2009).

1. WHAT, Memiliki fokus pada relasi entitas di dalam organisasi. Kolom ini juga sebagai gambaran dari kebutuhan organisasi yang memerlukan informasi berdasarkan data yang tersedia.

2. HOW, Memiliki fokus akan proses dan fungsi, terutama pada masukan dan keluaran yang dihasilkan. Kolom ini juga memberikan penjelasan fungsional dari komponen sistem informasi

3. WHERE, Berfokus pada lokasi kerja dari organisasi, biasanya digambarkan melalui sebuah jaringan berupa node-node atau link-link.

4. WHO, Membahas bagaimana pengalokasian sumber daya manusia serta struktur dan tanggung jawab didalam organisasi.

5. WHEN, Memiliki fokus pada waktu dan siklus. Berfungsi dalam melakukan gambaran setiap kegiatan yang memiliki hubungan dalam membangun kriteria kinerja.

6. WHY, Menjelaskan mengenai motivasi, tujuan yang menjadi goal dari organisasi, dan usaha yang akan dilakukan untuk mencapai goal tersebut.

Pada dasarnya Zachman framework digunakan untuk melakukan pengelolaan artifak suatu enterprise. Arifak diartikan sebagai dokumentasi sebuah ilustrasi model, gambar, diagram ,ataupun dokumen. Dengan digunakanya kerangka kerja Zachman, perancangan sistem informasi suatu enterprise dapat difokuskan pada artifak yang berguna sesuai kebutuhan, dan menghindari artifak yang bias, yang sering mengalihkan perhatian utama dalam melakukan perancangan dan perencanaan untuk mengidentifikasi masalah yang sesungguhnya (Surendro, 2009). Kelebihan lain yang didapatkan dari penggunaan Zachman framework adalah terdokumentasinya dari proses-proses perencanaan, perancangan, dan implementasi sistem informasi secara detil. Seperti yang disebutkan pada bagian sebelumnya bahwa Zachman framework terdapat enam aspek fokus pada setiap sudut pandang perspektif, dimana aspek tersebut dapat juga berguna sebagai pendokumentasian yang detil dalam sistem informasi (Slameto, Utami, \& Pangera, 2013).

\section{HASIL DAN PEMBAHASAN}

Digunakannya Zachman Framework dalam perancangan dan implementasi pada penelitian ini adalah untuk mengakomodasi seluruh pihak (Perspektif) yang terlibat, sehingga masing-masing pihak dapat memberikan pandangan yang bernilai pada Sistem yang akan terwujud. Tabel 3.5 merupakan matriks Zachman Framework yang digunakan dalam penelitian ini 
Tabel 3.5 Matriks Zachman Framework

\begin{tabular}{|c|c|c|c|c|c|c|}
\hline & $\begin{array}{l}\text { DATA } \\
\text { What }\end{array}$ & $\begin{array}{c}\text { FUNCTION } \\
\text { How }\end{array}$ & $\begin{array}{l}\text { NETWO } \\
\text { RK } \\
\text { Where }\end{array}$ & $\begin{array}{c}\text { PEOPLE } \\
\text { Who }\end{array}$ & $\begin{array}{l}\text { TIME } \\
\text { When }\end{array}$ & $\begin{array}{c}\text { MOTIVATI } \\
\text { ON } \\
\text { Why }\end{array}$ \\
\hline $\begin{array}{c}\text { SCOPE } \\
\text { (CONTEX } \\
\text { TUAL) } \\
\text { Planner }\end{array}$ & $\begin{array}{l}\text { Data Kelurahan, } \\
\text { Form, Dokumen }\end{array}$ & $\begin{array}{c}\text { Olah data } \\
\text { kependuduk } \\
\text { an, } \\
\text { pelayanan } \\
\text { publik dan } \\
\text { manajemen } \\
\text { surat }\end{array}$ & $\begin{array}{c}\text { Keluraha } \\
\mathrm{n} \\
\text { Triwidadi }\end{array}$ & $\begin{array}{c}\text { Struktur } \\
\text { Organisa } \\
\text { si } \\
\text { Keluraha } \\
\text { n }\end{array}$ & $\begin{array}{c}\text { Kegiatan } \\
\text { utama: } \\
\text { Pelayana } \\
n \\
\text { masyarak } \\
\text { at } \\
\text { Triwidadi }\end{array}$ & $\begin{array}{c}\text { Visi Misi } \\
\text { Kelurahan } \\
\text { Triwidadi }\end{array}$ \\
\hline $\begin{array}{c}\text { ENTERPR } \\
\text { ISE } \\
\text { MODEL } \\
\text { (CONCEP } \\
\text { TUAL) } \\
\text { Owner }\end{array}$ & $\begin{array}{l}\text { Detail deskripsi } \\
\text { Data di Kelurahan }\end{array}$ & $\begin{array}{l}\text { Ilustrasi } \\
\text { model } \\
\text { proses } \\
\text { aktifitas }\end{array}$ & $\begin{array}{c}\text { Bidang- } \\
\text { bidang } \\
\text { Keluraha } \\
\mathrm{n} \text { terkait } \\
\text { Sistem }\end{array}$ & $\begin{array}{c}\text { Calon } \\
\text { penggun } \\
\text { a sistem } \\
\text { di } \\
\text { keluraha } \\
n\end{array}$ & $\begin{array}{c}\text { Time } \\
\text { Schedule } \\
\text { keseluruh } \\
\text { an }\end{array}$ & $\begin{array}{c}\text { Penerapan } \\
\text { UU E- } \\
\text { governmen } \\
\text { t untuk } \\
\text { pelayanan } \\
\text { publik dan } \\
\text { Keterbukaa } \\
\text { n Informasi } \\
\text { Publik }\end{array}$ \\
\hline $\begin{array}{c}\text { SYSTEM } \\
\text { MODEL } \\
\text { (LOGICAL } \\
\text { ) } \\
\text { Designer }\end{array}$ & $\begin{array}{c}\text { ERD } \\
\text { ternormalisasi }\end{array}$ & $\begin{array}{l}\text { Usecase } \\
\text { dan } \\
\text { Sequence } \\
\text { diagram }\end{array}$ & $\begin{array}{l}\text { Distribusi } \\
\text { Topologi } \\
\text { Jaringan }\end{array}$ & $\begin{array}{l}\text { Rancang } \\
\text { an } \\
\text { Interface } \\
\text { Sistem } \\
\text { Informasi }\end{array}$ & $\begin{array}{c}\text { Siklus } \\
\text { Kompone } \\
n\end{array}$ & $\begin{array}{l}\text { Rule User } \\
\text { Level }\end{array}$ \\
\hline $\begin{array}{c}\text { TECHNOL } \\
\text { OGY } \\
\text { MODEL } \\
\text { (PHYSICA } \\
\text { L) } \\
\text { Builder }\end{array}$ & Struktur Tabel & $\begin{array}{l}\text { Class } \\
\text { Diagram }\end{array}$ & $\begin{array}{c}\text { Arsitektur } \\
\text { Teknolog } \\
\text { i yang } \\
\text { digunaka } \\
n\end{array}$ & $\begin{array}{l}\text { Prototype } \\
\text { Sistem } \\
\text { Informasi }\end{array}$ & $\begin{array}{l}\text { Siklus } \\
\text { Kompone } \\
\text { n (User } \\
\text { Level) }\end{array}$ & $\begin{array}{l}\text { Activity } \\
\text { Diagram }\end{array}$ \\
\hline $\begin{array}{c}\text { DETAIL } \\
\text { REPRESE } \\
\text { NTATION } \\
\text { (OUT-OF- } \\
\text { CONTEXT } \\
\text { ) } \\
\text { Sub } \\
\text { Contracto } \\
r\end{array}$ & $\begin{array}{l}\text { Data Definition } \\
\text { Lenguage (DDL) }\end{array}$ & $\begin{array}{l}\text { Detail } \\
\text { Source } \\
\text { Code }\end{array}$ & $\begin{array}{c}\text { Konfigura } \\
\text { si } \\
\text { Jaringan }\end{array}$ & $\begin{array}{c}\text { Hak } \\
\text { Akses } \\
\text { Penggun } \\
\text { a Aplikasi }\end{array}$ & $\begin{array}{c}\text { Siklus } \\
\text { Sistem } \\
\text { Informasi }\end{array}$ & $\begin{array}{l}\text { Aturan } \\
\text { proses } \\
\text { coding }\end{array}$ \\
\hline
\end{tabular}

\subsubsection{Perspektif Planner}

Dalam penelitian ini, Planner mencakup semua pihak yang terlibat dalam perencanaan Sistem Informasi yang akan diwujudkan. Pihak yang terlibat dalam perencanaan adalah kelurahan Triwidadi (lurah dan kasie terkait) yang dibantu oleh peneliti, dan pihak kecamatan Pajangan khususnya bidang pembangunan. Definisi kolom-kolom terkait dalam prespektif Planner adalah sebagai berikut. 


\subsubsection{Kolom What (Data Dasar)}

Kolom What dalam perspektif Planner akan memberikan gambaran awal data-data yang penting atau yang dapat digunakan dan dilibatkan dalam proses Sistem Informasi yang akan dibangun. Data-data tersebut adalah sebagai berikut:

1. Data Penduduk

Data penduduk yang dimiliki oleh pemerintah desa adalah berupa kartu keluarga $(\mathrm{KK})$ yang didalamnya tercantum data masing-masing individu anggota keluarga dan data setiap keluarga.

2. Data Penerima Beras Sejahtera (Rastra)

Data penerima beras sejahtera (Rastra) adalah data warga yang dianggap kurang mampu secara ekonomi di kelurahan Triwidadi. Karena data ini dikeluarkan setiap tahun oleh Badan Pusat Statistik berdasarkan survei terhadap masing-masing kondisi ekonomi warga.

3. Dokumen Pelayanan Publik

Dalam melakukan pelayanan publik, pemerintah desa Triwidadi tentu tidak lepas dari menerbitkan dokumen untuk kepentingan masyarakat, seperti surat pengantar, surat keterangan, dan lain sebagainya.

4. Data surat masuk

Data surat masuk berisikan rekam jejak tentang surat yang masuk di kelurahan Triwidadi, seperti asal instansi pengirim surat, waktu surat diterima, dan lain sebagainya.

\subsubsection{Kolom How (Proses yang terakomodasi)}

Kolom How dalam perspektif Planner akan merincikan proses apa sajakah yang kemungkinan dapat terakomodasi dan tersedia dalam Sistem yang akan dibangun. Prosesproses tersebut antara lain sebagai berikut:

1. Proses pengolahan data kependudukan

Proses ini akan melakukan pengolahan data kependudukan yang bersumber dari data kartu keluarga. Dalam proses pengolahan data kependudukan akan mencakup input data kependudukan baru, edit data kependudukan (update), dan rekap data penduduk yang telah meninggal ataupun pindah alamat.

2. Proses pelayanan publik

Dalam proses pelayanan publik akan dilakukan pencetakan formulir ataupun dokumen surat yang diajukan oleh masyarakat, yang dalam membuat formulir dan dokumen surat tersebut dengan memanfaatkan data kependudukan. Untuk beberapa formulir dan dokumen surat dapat disetujui pengajuanya jika sesuai dengan verifikasi pada data kependudukan.

3. Proses manajemen surat

Proses manajemen surat akan melibatkan beberapa pihak terkait yaitu bagian umum, lurah dan bagian yang di disposisi oleh lurah. Ketika terdapat surat baru masuk, bagian umum akan mengirimkan ke lurah, dan lurah akan mendisposisikan ke bagian terkait.

\subsubsection{Kolom Where (Lokasi Utama)}

Pada kolom Where dalam perspektif Planner akan mendefinisikan lokasi utama dari terjadinya proses-proses yang telah disetujui. Lokasi utama adalah pada Kelurahan desa Triwidadi yang memiliki alamat di Jalan Kayuhan-Sudimoro, Triwidadi, Pajangan, Bantul, Daerah Istimewa Yogyakarta.

\subsubsection{Kolom Who (Struktur Organisasi)}

Struktur Organisasi Kelurahan desa Triwidadi seperti pada gambar 3.2 adalah yang melakukan planning dalam pembangunan sistem yang akan dibangun, dan juga yang akan mendefinisikan "who" atau orang-orang yang terlibat dalam sistem ini. 


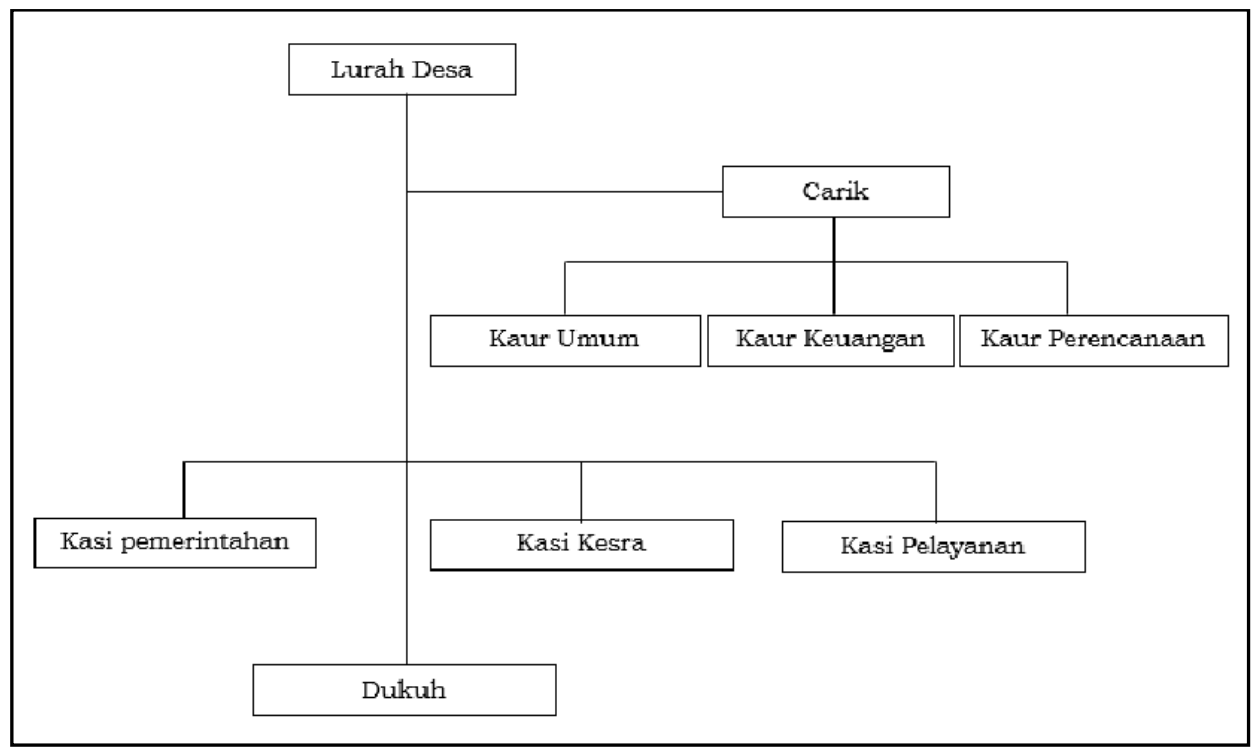

Gambar 3.2 Struktur Organisasi Kelurahan Triwidadi

\subsubsection{Kolom When (Waktu Proses Dijalankan)}

Kolom When merinci kapan proses-proses tersebut akan dijalankan. Untuk proses pengelolaan data akan dilakukan ketika terjadi penambahan data baru dan perubahan data, kemudian untuk proses pelayanan publik akan dilakukan ketika terdapat pengajuan form atau dokumen surat dari masyarakat khususnya ketika jam kerja kelurahan yaitu pukul $07.00-15.00$ WIB. Selanjutnya proses manajemen surat terjadi ketika terdapat surat yang masuk di kelurahan Triwidadi.

\subsubsection{Kolom Why (Motivasi Planner)}

Salah satu misi kelurahan desa Triwidadi yang digunakan sebagai motivasi dalam pembangunan sistem informasi ini adalah yang berbunyi "Menciptakan pemerintah yang katalis dan dinamis dengan didukung kelembagaan yang efektif dan kinerja aparatur yang kompeten, serta pemanfaatan teknologi informasi. Pemerintah yang dapat memberi fasilitator dalam pembangunan bagi masyarakat, agar masyarakat dapat berperan sebagai pelaku sekaligus sebagai sasaran pembangunan, sehingga proses pencapaian tujuan pembangunan dapat berjalan secara efektif dan efisien. Untuk mewujudkan pemerintah yang demikian dibutuhkan sistem kelembagaan dan ketata laksanaan pemerintah desa yang bersih, efektif, efisien, transparan, profesional, dan akuntabel dengan didukung dengan sistem pengawasan". Melalui pembangunan sistem infomasi ini, adalah sebagai implementasi dalam mencapai misi yang telah disebutkan diatas, dimana dalam menciptakan pemerintah yang katalis, dinamis, dan efektif telah di dukung dengan teknologi informasi.

\subsubsection{Perspektif Owner}

Owner dalam penelitian ini adalah pihak kelurahan khususnya lurah desa selaku jajaran pemerintah desa Triwidadi. Definisi kolom-kolom terkait dalam perspektif Owner adalah sebagai berikut.

\subsubsection{Kolom What (Penjabaran Data Dasar)}

Kolom What dalam perspektif Owner akan menampilkan detail data yang dapat digunakan dalam pembangunan sistem di kelurahan. Data-data tersebut adalah sebagai berikut:

1.

Data Penduduk

Data penduduk yang berada di kantor kelurahan Triwidadi adalah berupa kartu keluarga masing-masing keluarga, yang didapatkan pihak kelurahan ketika warga akan melakukan pembuatan kartu keluarga baru ataupun melakukan updating data untuk keperluan tertentu. Bentuk data penduduk yang berupa kartu keluarga adalah seperti pada tabel 3.6 berikut. 
Tabel 3.6 Data Penduduk (Kartu Keluarga)

\begin{tabular}{|l|l|l|}
\hline No & JENIS DATA & CONTOH DATA \\
\hline 1 & Nomor Kartu Keluarga & 3402070305110039 \\
\hline 2 & Nama Kepala Keluarga & PONEM \\
\hline 3 & Alamat & BUTUH KIDUL \\
\hline 4 & RT/RW & $001 /-$ \\
\hline 5 & Kode Pos & 55751 \\
\hline 6 & Desa/Kelurahan & TRIWIDADI \\
\hline 7 & Kecamatan & PAJANGAN \\
\hline 8 & Kabupaten/Kota & BANTUL \\
\hline 9 & Provinsi & DAERAH ISTIMEWA YOGYAKARTA \\
\hline 10 & Nama Lengkap & PONEM \\
\hline 11 & Nomor Induk Kependudukan & 3402075002660001 \\
\hline 12 & Jenis Kelamin & PEREMPUAN \\
\hline 13 & Tempat Lahir & BANTUL \\
\hline 14 & Tanggal Lahir & 10-02-1966 \\
\hline 15 & Agama & ISLAM \\
\hline 16 & Pendidikan & TAMAT SD/SEDERAJAT \\
\hline 17 & Jenis Pekerjaan & BURUH TANI/PERKEBUNAN \\
\hline 18 & Status Perkawinan & BELUM KAWIN \\
\hline 19 & Status Hubungan Dalam Keluarga & KEPALA KELUARGA \\
\hline 20 & Kewarganegaraan & WNI \\
\hline 21 & Nomor Paspor & A7599272 \\
\hline 22 & Nomor Kitap & 2D1ZA0006L \\
\hline 23 & Nama Ayah & MARTO DIKROMO \\
\hline 24 & Nama Ibu & REDJO UTOMO \\
\hline & & \\
\hline
\end{tabular}

2. Data Penerima Beras Sejahtera (Rastra)

Data penerima beras sejahtera digunakan kelurahan untuk melakukan filter terhadap penerbitan surat keterangan tidak mampu. Karena data penerima beras sejahtera (Rastra) adalah data warga yang kurang mampu secara ekonomi menurut survei yang dilakukan Badan Pusat Statistik setiap tahun. Bentuk data penerima beras sejahtera (Rastra) adalah seperti pada tabel 3.7 berikut.

Tabel 3.7 Data Penerima Beras Sejahtera (Rastra)

\begin{tabular}{|l|l|l|}
\hline No & JENIS DATA & CONTOH DATA \\
\hline 1 & Nama Desa & Triwidadi \\
\hline 2 & Nama Pengurus & Sutarmi \\
\hline 3 & Nama Suami & Budi Santoso \\
\hline 4 & Nomor Induk Kependudukan Suami & 3374031107790001 \\
\hline 5 & Nama Istri & Sutarmi \\
\hline 6 & Nomor Induk Kependudukan Istri & 3374036411810002 \\
\hline 7 & Alamat & Blabak \\
\hline
\end{tabular}

3. Dokumen Pelayanan Publik

Dokumen publik yang dilayani dan diterbitkan untuk kepentingan masyarakat oleh kelurahan Triwidadi adalah sebagai berikut:

a. Surat Keterangan Tidak Mampu

b. Surat Keterangan Kelakuan Baik

c. Surat Keterangan Beda Identitas

d. Surat Keterangan Umum

e. Surat Keterangan Kelahiran (Dinas Dukcapil secara online melalui kelurahan)

f. Surat Keterangan Untuk Nikah (Model N-1) (KUA melalui kelurahan)

g. Surat Keterangan Asal Usul (Model N-2) (KUA melalui kelurahan)

h. Surat Keterangan Mempelai (Model N-3) (KUA melalui kelurahan)

i. Surat Keterangan Tentang Orang Tua (Model N-4) (KUA melalui kelurahan) 
j. $\quad$ Surat Keterangan Izin Orang Tua (Model N-5) (KUA melalui kelurahan)

k. Surat Keterangan Kematian Suami/Istri (Model N-6) (KUA melalui kelurahan)

I. Surat Keterangan Pemberitahuan Menikah (Model N-7) (KUA melalui kelurahan)

4. Data Surat Masuk

Surat masuk yang diterima bagian umum, akan dituliskan dalam sebuah lembar disposisi yang akan diserahkan ke lurah untuk dilakukan disposisi terhadap bagian terkait. Bentuk data lembar disposisi tersebut adalah sebagai berikut:

Tabel 3.8 Data lembar disposisi

\begin{tabular}{|c|c|c|}
\hline No & JENIS DATA & CONTOH DATA \\
\hline 1 & Index & Permohonan \\
\hline 2 & Kode & 005 \\
\hline 3 & Nomor Urut & 110 \\
\hline 4 & Tanggal Penyelesaian & 13-03-2017 \\
\hline 5 & Isi Ringkas & $\begin{array}{l}\text { Permohonan pengiriman } \\
\text { peserta seleksi kalpataru tahun } 2017 . \\
\text { Profil peserta dikirim paling lambat } \\
\text { Rabu 15-03-2017 di Kasie. } \\
\text { Pembangunan Lingkungan Hidup } \\
\text { Kecamatan pajangan. }\end{array}$ \\
\hline 6 & Asal Surat & Camat Pajangan \\
\hline 7 & Tanggal Surat & 13-03-2017 \\
\hline 8 & Nomor Surat & $005 / 83$ \\
\hline 9 & Lampiran & Hardcopy Surat \\
\hline 10 & Diteruskan Kepada bagian & Carik \\
\hline 11 & Instruksi/Informasi & $\begin{array}{l}\text { Mohon dikoordinasikan dengan Kasie. } \\
\text { Kesra. }\end{array}$ \\
\hline
\end{tabular}

\subsubsection{Kolom How (Penggambaran Proses)}

Dalam kolom How akan dijelaskan bagaimana proses untuk pengolahan data dasar keluarga, proses pelayanan publik, dan proses surat menyurat sebelum dilakukan penelitian ini yang akan disajikan dalam diagram seperti pada gambar 3.3, gambar 3.4, dan gambar 3.5.

\section{KESIMPULAN}

Telah dapat dibangun suatu sistem informasi pemerintahan desa menggunakan framework zachman berbasis web, dengan bahasa pemrograman PHP Code Igniter

\section{DAFTAR PUSTAKA}

Abdul, K. (2003). Pengenalan Sistem Informasi. Yogyakarta: Andi.

Airlangga, A. F. F. I., \& Sensuse, D. I. (2012). Pengaruh e-government terhadap kemampuan knowledge sharing pemerintah (studi kasus pada pemerintah daerah DKI Jakarta). STUDIA INFORMATIKA: JURNAL SISTEM INFORMASI, 5(2). Retrieved from http://journal.uinjkt.ac.id/index.php/sisteminformasi/article/viewFile/292/2394

Al-Nasrawi, S., \& Ibrahim, M. (2013). An enterprise architecture mapping approach for realizing e-government. In Communications and Information Technology (ICCIT), 2013 Third International Conference on (pp. 17-21). IEEE.

Batinggi, A., \& Ahmad, B. (2014). Manajemen Pelayanan Umum. Retrieved from http://repository.ut.ac.id/4256/1/IPEM4429-M1.pdf

Christianti, M., \& Try, F. D. (2009). Pemodelan Sistem Informasi pada CV Cihanjuang Inti Teknik dengan Menggunakan Zachman Framework. Jurnal Sistem Informasi, 4. 
Depkominfo. (2006). RANCANGAN BLUE PRINT E-GOVERNMENT (PEMERINTAH DAERAH). Depkominfo. Retrieved from http://jurnalkomputer.com/attachments/article/143/BLUE\%20PRINT\%20EGOVERNMENT.pdf

Hartono, D. U., \& Mulyanto, E. (2010). Electronic Government Pemberdayaan Pemerintahan dan Potensi Desa Berbasis Web. Jurnal Teknologi Informasi, 6(1), 9-21.

IFEAD. (2003). Institute For Enterprise Architecture Developmenst (IFEAD)/ Research. Retrieved July 15, 2017, from https://www.enterprise-architecture.info/research.html

KEMENDAGRI. (2015). PERATURAN MENTERI DALAM NEGERI REPUBLIK INDONESIA NOMOR 84 TAHUN 2015 TENTANG SUSUNAN ORGANISASI DAN TATA KERJA PEMERINTAH DESA. KEMENDAGRI. Retrieved from http://www.keuangandesa.com/wp-content/uploads/2015/02/Permendagri-Nomor-84Tahun-2015-Susunan-Organisasi-dan-Tata-Kerja-Pemerintah-Desa.pdf

Nadir, S. (2013). Otonomi Daerah Dan Desentralisasi Desa: Menuju Pemberdayaan Masyarakat Desa. JPP (Jurnal Politik Profetik), 1(1). Retrieved from http://journal.uinalauddin.ac.id/index.php/jpp/article/view/1621

Priantoto, W. (2008). PERENCANAAN ARSITEKTUR ENTERPRISE UNTUK PENGEMBANGAN e-GOVERNMENT PADA PEMERINTAH KABUPATEN BARITO UTARA Studi Kasus $\square$ : PELAYANAN PERIZINAN. IPB. Retrieved from http://repository.ipb.ac.id/handle/123456789/22768

Priyanti, D., \& Iriani, S. (2013). Sistem Informasi Data Penduduk Pada Desa Bogoharjo Keccamatan Ngadirojo Kabupaten Pacitan. IJNS-Indonesian Journal on Networking and Security, 2(4). Retrieved from http://ijns.org/journal/index.php/ijns/article/view/181

Saragih, H., \& Yudanto, B. W. (2013). SISTEM INFORMASI LEMBAGA PEMERINTAHAN DI INDONESIA MELALUI ELECTRONIC GOVERNMENT (E-GOVERNMENT) DENGAN OPEN SOURCE SOFTWARE. Jurnal Teknik Dan IImu Komputer, 2.

Setiawan, E. B. (2009). Pemilihan EA Framework. In Seminar Nasional Aplikasi Teknologi Informasi (SNATI). Retrieved from http://jurnal.uii.ac.id/index.php/Snati/article/download/1091/979

Setiawan, V. A. (2007). Analisis dan perancangan sistem informasi. Retrieved from http://repository.amikom.ac.id/files/Publikasi_07.11.1638.pdf

Slameto, A. A., Utami, E., \& Pangera, A. A. (2013). PENERAPAN ZACHMAN FRAMEWORK DALAM MERANCANG SISTEMPELAPORAN KERUSAKAN KOMPUTER. SEMNASTEKNOMEDIA ONLINE, 1(1), 17-27.

Sosiawan, E. A. (2015). Tantangan dan Hambatan dalam implementasi E-Government di Indonesia. In Seminar Nasional Informatika (SEMNASIF) (Vol. 1). Retrieved from http://jurnal.upnyk.ac.id/index.php/semnasif/article/view/760

Supangkat, S. H., \& Negara, I. (2006). Framework Strategi Implementasi E-Government. Prosiding Konferensi Nasional Teknologi Informasi \& Komunikasi Untuk Indonesia, 3-4.

Surendro, K. (2009). Pengembangan Rencana Induk Sistem Informasi. Informatika Bandung.

Veronica, A. K., Rosyani, \& Ratnaningsih. (2012). PENERAPAN E-GOVERNMENT MENDORONG TERWUJUDNYA PENYELENGGARAAN PEMERINTAHAN YANG BAIK DI INDONESIA (Tanggapan terhadap Instruksi Presiden Republik Indonesia Nomor 3 Tahun 2003). EKOTON, 8(2). Retrieved from http://ejournal.unsrat.ac.id/index.php/EKOTON/article/view/272 
Widodo, A. P. (2010). Enterprise architecture model untuk aplikasi government. Jurnal Masyarakat Informatika, 1(1), 23-30.

Yunis, R., \& Theodora, T. (2012). Penerapan Enterprise Architecture Framework untuk Pemodelan Sistem Informasi. JSM (Jurnal SIFO Mikroskil), 13(2), 159-168.

Yustisia, T. V. (2015). Undang-Undang Nomor 6 Tahun 2014 Tentang Desa dan Peraturan Terkait VisiMedia.

Retrieved

from

http://books.google.com/books?hl=en\&lr=\&id=2oCwCgAAQBAJ\&oi=fnd\&pg=PA3\&dq= $\% 22$ guna+kesejahteraan $\% 22+\% 22$ budaya+masyarakat+Desa,+serta+kemampuan+da $\mathrm{n}+$ potensi $\% 22+\% 22$ Desa+baru+di+luar+Desa+yang\%22+\%22Desa+sesuai+dengan+k etentuan+peraturan $\% 22+\% 22$ dengan+mempertimbangkan+prakarsa+masyarakat+Des a,+asal+usul,+adat+istiadat, \%22+\&ots=ikJbNKwjiP\&sig=nDuOceEqIWbyKXgCSGwi$61 \mathrm{Vzlk}$ 